\title{
EFFECTIVENESS OF WEB 2.0 TECHNOLOGIES IN DISTANCE
}

\section{LEARNING}

By

\author{
Syed Yasir Ali Gilani* \\ Tanvir-Uz-Zaman** \\ Mamonah Ambreen***
}

\begin{abstract}
In the present research an attempt has been made to explore the "Effectiveness of Web 2.0 Technologies in Distance Learning”. Web 2.0 skills had a significant positive outcome on academic achievement of learners. Objectives of this study were to explore the potential role of web 2.0 technologies in Distant Learning System (DLS), to find out the problems in adopting emerging hi-tech trends for distance learners and to conduct an analysis of effectiveness of web 2.0 technologies. The study was experimental in nature. The pretest-posttest equivalent groups design was used for the treatment. The population of this study comprisesd of 89 students enrolled in M.Phill Education Couse Code No. 3705 for semester Spring-2014. The study sample was divided into two equal groups that are; experimental and control groups, the experimental group was observed in a test of statistical significance. On the basis of the research finding, it was concluded that the web 2.0 tools were more effective than ordinary technologies in the increasing average academic achievement of distance learners and web skills were more helpful in refining average problem solving proficiencies of distance learners as compared with traditional strategies.
\end{abstract}

Keywords: Web 1.0, Web 2.0 Technologies, Effectiveness, Distance learning

* Scholar Session 2012-14 at Department of Distance, Non Formal \& Continuing Education, Allama Iqbal Open University, Islamabad.

** Dean, Faculty of Education, Allama Iqbal Open University, Islamabad.

*** Lecturer, Department of Distance, Non Formal \& Continuing Education, Allama Iqbal Open University, Islamabad. 


\section{Introduction}

According to Redecker et al. (2009, p.207) the World Wide Web is not identical to the internet rather it is most prominent component of the internet which may be described as a techno-social system to interact humans based on hi-tech networks. The concept of the techno social system denotes a structure that increases human perception, cooperation, and communication; Perception is the essential requirement to interconnect and the precondition to co-operate. In other words collaboration needs communication and communication needs perception, so the web is the largest transformableinformation standard.

According to Berners-Lee (1989, p.111) web 1.0 is the $1^{\text {st }}$ generation of the web which can be described as the read-only web and also known as cognition system. The primary web delivered a restricted user interactions or content contributions and is used only for information searching and viewing. Dougherty (2004, p.81) defined web 2.0 technologies as a read-write web. The aids of web 2.0 allows managing and assembling large worldwide crowds with conjoint interests in social collaborations. There have been several modifications between web 2.0 and web 1.0 uptil now.

Tim Burners-Lee (1989, p.205) says that "the vision behind the web was to make the people able to communicate with each other by sharing information which will produce a common information space”. The Web 1.0 was mainly a read-only, static and somewhat mono-directional. The web pages developed by using Web 1.0 technologies included static HTML pages that shortened occasionally. The main goal of those websites was to publish the material for everyone at any time and to establish an online presence.

Dougherty (2004, p. 61) "web 2.0 is known as the people-centric web, dynamic web, and read-write web, enabling the websites for writing along with reading makes the websites bidirectional instead of traditional unidirectional (read only)". While Web 2.0 is not only an innovative version of web 1.0; flexible web design, creative reuse, updates, combined content creation and modification were gathered through web 2.0.

Simons \& Salomon (2005, p.21) stated that "all the latest technologies which are made to assist the teaching learning process are emergent methodological trends in education”. The emergent methodological trends cannot be neglected in distance education system; because of the comfort the learner is a main requirement of distance education and by using emerging trends a distance learner can be enabled in the best way. The usage of emerging methodologies, teaching learning procedure may be more flexible, more comfortable and more convenient for both instructor and student.

\section{Literature Review}

According to Harris, Smith\& Carey (2011, p. 88) the features offered by web 2.0 technologies has originated academic professionals to revise the development of learning techniques and approaches. The editable, open access environment of web 2.0 boosts the innovative collaboration of ideas, the creation of equitable visual and concrete learning environments and opportunity for academics to improve contemporary assessment tasks. Web 2.0 can theoretically develop the learning experience through facilitating group responses, enabling access to external experts, or by encouraging and the formation of communities of practice. Some examples include; web based communities, hosted services, web applications, social networking sites, video sharing sites, wikis and blogs. Distance learners and instructors enjoy a more 
energetic educational-experience at less cost and much effectiveness as face-to-face learning.

According to Emdon, J.V (2011, p. 92) "the web 2.0 tools have raised many issues that are required to be addressed with caution. Some major issues are as follows:

- Hesitations about relevancy and consistency

- Copyright and plagiarism concerns

- Privacy and safety concerns

- Data protection and data storage anxieties

- Concerns about emerging into real life skills" (p.92).

-

Sutton, L. (2000, p.18) concluded that in web 2.0 the formation of information on the web is a part of our practice as the judgment or reading of data has been in web 1.0. while in web 2.0 the content produced by regular users would be more important. According to Simons (2005, p.120) web learning is moving towards web 2.0 which is a two way infrastructures medium and becoming popular in the field of distance education because it gives prospect to the learners to communicate with the tutors and instructors. So it implies that Web 2.0 is a bidirectional medium, representing the next stage of usage of the internet. All new devices and technologies have their positive effect, it is the need of the time to learn the uses of new devices and latest software's so that the learners of distance education can be facilitated and tutors should also need to learn the uses of upcoming technology to meet the emerging teaching needs in distance education system.

\section{Objectives of the Study}

Following objectives pointed at achieving the desired theoretical substance:

1. Explore the potential role of web 2.0 technologies in DLS.

2. Find out the problems in adopting emerging hi-tech trends for distance learners.

3. Conduct an essential analysis of effectiveness of web 2.0 technologies.

\section{Hypothesis}

The hypothesis of the study was "there is no significant difference between the mean pretest posttest academic achievement scroes of the distance learners to be taught through web 2.0 technologies”.

\section{Methodology}

The study was experimental in nature. This study was considered to find out the "Effectiveness of Web 2.0 Tools in Distance Learning" on the completion of pretest posttest and problem solving competencies of distance learners.

\section{Research design / treatment of the study}

A Pretest-Posttest equivalent groups design was used for this treatment. The symbolic representation of this design is as follows:
$\mathbf{R}$
$\mathrm{E}=\mathbf{O}_{1} \quad \mathbf{T}$
$\mathbf{O}_{2}$
$\mathbf{R}$
C $=$
$\mathbf{O}_{3}$
$\mathbf{O}_{4}$ 
The pre-test scores used to examine the pre-knowledge of the participants, where as the post-test scores gained after experimental treatment on the basis of these results reliability of the pretest posttest found satisfactory. The difference between the means of the pretest and posttest scores was tested at 0.05 levels by relating paired sample $t$ test.

\section{Respondents}

All the 89 students of M.Phil. (Education) enrolled in course code 3705 (computer applications for education) for semester spring 2014 at Allama Iqbal Open University, Islamabad comprised asrespondents of the study. According to the nature of the study sample was divided into experimental and control groups, the experimental group was observed in a test of statistical significance.

\section{Data collection and Analysis}

the data was collected through researcher made tests from both groups after an experiment in which the relevant variables operated through pretest posttest. The pretest posttest statements directed during workshop course code 3705 (Group A) semester spring 2014. During the period of data collection, students consumed about 3 hours of instructional time. Instructional treatments were given for half an hour to both instructional groups and the additional time commitment (45 minutes) enthusiastic to data collection outside of the scheduled class periods on the first and last day of the management. In this research study, data assortment was done through the administration of three divergent categories of semi standardized and selfdeveloped tests.

1. Achievement Test (AT)

2. Problem Solving Capabilities Test (PSCT)

3. Retention Test (RT)

Achievement test and problem solving capability test were accomplished to obtain pretest scores just before the beginning of treatment after the completion of treatment (teaching) during workshop of course-code 3705 (Group A) semester spring 2014, the post-test was administered immediately to obtain posttest scores in achievement test.

In order to find out the effectiveness of web 2.0 technologies in distance learning system, the paired sample t-test was used. The null hypotheses were established which accepted or rejected on the basis of comparison of calculated values (known as tvalues) and tabulated values (known as p-values). The data were investigated by the application of paired t-test using SPSS version 16.

\section{Results}

The data collected through pretest posttest and problem solving capability test were analyzed through descriptive statistics and inferential analysis. In this program the data were analyzed through mean and paired sample $t$-test.

Research Question:Web 2.0 tools regulate the learning procedure to the needs of distance learners.

\section{Hypothesis}

There is no notable difference between the mean pretest posttest academic achievement scores of the students taught through web 2.0 technological tools during 
workshop of course (computer applications for education) code 3705 (Group A) semester spring 2014 at Allama Iqbal Open University.

Table 1

Web 2.0 tools adjust the learning process to the needs and desire of distance learners $(\mathbf{n}=30)$

\begin{tabular}{|c|c|c|c|c|c|c|c|c|}
\hline \multirow[b]{3}{*}{ Statement } & \multicolumn{5}{|c|}{ Paired Differences } & \multirow[b]{3}{*}{$\mathrm{t}$} & \multirow[b]{3}{*}{$\mathrm{df}$} & \multirow{3}{*}{$\begin{array}{c}\text { P- } \\
\text { Value }\end{array}$} \\
\hline & \multirow[b]{2}{*}{ Mean } & \multirow{2}{*}{$\begin{array}{c}\text { Std. } \\
\text { Deviation }\end{array}$} & \multirow{2}{*}{$\begin{array}{l}\text { Std. } \\
\text { Error } \\
\text { Mean }\end{array}$} & \multicolumn{2}{|c|}{$\begin{array}{l}\text { 95\% Confidence } \\
\text { Interval of the } \\
\text { Difference }\end{array}$} & & & \\
\hline & & & & Lower & Upper & & & \\
\hline $\begin{array}{l}\text { Pair } 1 \\
\text { Web } 2.0 \text { tools adjust } \\
\text { the learning process } \\
\text { to the needs and } \\
\text { desire of distance } \\
\text { learner.-Q.1.Post }\end{array}$ & -1.50000 & .97379 & .17779 & -1.86362 & -1.13638 & -8.437 & 29 & .000 \\
\hline
\end{tabular}

Table 1 shows $t=8.437, \mathrm{df}=29$ with P-Value $=0.000$. As $p$-value is less than level of significance, $\alpha=0.05$. There is a significant difference in the mean pretest posttest scores of the students of experimental group at $\alpha=0.05$ with the significance of pretest posttest academic achievement and knowledge exploration process. Therefore the null hypothesis, "there is no significant difference between the mean pretest posttest academic achievement scores of the distance learners to be taught through web 2.0 technologies” was rejected.

esearch Question

Does web 2.0 technologies for distance learners are more useful than conventional methods?

Hypothesis; $\mathrm{H} 0: \mu 1=\mu 2 \& \mathrm{H} 1: \mu 1 \neq \mu 2$

Table 2

The utilization of web 2.0 technologies for distance learners is more useful than conventional methods $(n=30)$

\begin{tabular}{|c|c|c|c|c|c|c|c|c|}
\hline \multirow[b]{3}{*}{ Statement } & \multicolumn{5}{|c|}{ Paired Differences } & \multirow[b]{3}{*}{$\mathrm{t}$} & \multirow[b]{3}{*}{ df } & \multirow{3}{*}{$\begin{array}{c}\text { P- } \\
\text { Value }\end{array}$} \\
\hline & \multirow[b]{2}{*}{ Mean } & \multirow{2}{*}{$\begin{array}{c}\text { Std. } \\
\text { Deviation }\end{array}$} & \multirow{2}{*}{$\begin{array}{l}\text { Std. Error } \\
\text { Mean }\end{array}$} & \multicolumn{2}{|c|}{$\begin{array}{l}\text { 95\% Confidence } \\
\text { Interval of the } \\
\text { Difference }\end{array}$} & & & \\
\hline & & & & Lower & Upper & & & \\
\hline $\begin{array}{l}\text { Pair } 1 \\
\text { The utilization of web } 2.0 \\
\text { technologies for distance } \\
\text { learners is more useful than } \\
\text { conventional methods. - } \\
\text { Q.1.Post }\end{array}$ & -1.70000 & 1.08755 & .19856 & -2.10610 & -1.29390 & -8.562 & 29 & .000 \\
\hline
\end{tabular}

Table 2 shows $t=8.562$, $\mathrm{df}=29$ with $P$-value $=0.000$. As $P$-value less than level of significance, $\alpha=0.05$. There is a significant difference between the pretest posttest problem solving capabilities during adoption of web 2.0 technologies by experimental 
group at $\alpha=0.05$ in both experiments. Therefore, null hypothesiswhich states, "there is no significant difference between the pretest posttest academic achievement scores of the students taught through web 2.0 technologies" was rejected.

\section{Research Question}

The learning skills could be improved by using web 2.0 technological innovations. Hypothesis; H0: $\mu 1=\mu 2$ \& H1: $\mu 1 \neq \mu 2$

Table 3

The learning skills could be improved by using web 2.0 technological innovations $(n=30)$

\begin{tabular}{|c|c|c|c|c|c|c|c|c|}
\hline \multirow[b]{3}{*}{ Statement } & \multicolumn{5}{|c|}{ Paired Differences } & \multirow[b]{3}{*}{$\mathrm{t}$} & \multirow[b]{3}{*}{ df } & \multirow{3}{*}{$\begin{array}{c}P- \\
\text { Value }\end{array}$} \\
\hline & & & $\begin{array}{l}\text { Std. } \\
\text { Error }\end{array}$ & $\begin{array}{r}95 \% \mathrm{C} \\
\text { Inter } \\
\text { Dif }\end{array}$ & $\begin{array}{l}\text { dence } \\
\text { f the } \\
\text { nce }\end{array}$ & & & \\
\hline & Mean & Deviation & Mean & Lower & Upper & & & \\
\hline $\begin{array}{l}\text { Pair } 1 \\
\text { The learning skills could be } \\
\text { improved by using web } 2.0 \\
\text { technological innovations. - } \\
\text { Q.1.Post }\end{array}$ & -1.40000 & 1.24845 & .22793 & -1.86618 & -.93382 & -6.142 & 29 & .000 \\
\hline
\end{tabular}

* Level of Significance $\alpha=0.05, \mathrm{df}=29$, Paired Samples t-test

Table 3 depicts $t=6.142$, $\mathrm{df}=29$ with $p$-value $=0.000$. As $p$-value is less than level of significance, $\alpha=0.05$. There is a significant difference between the pretest posttest scores during adoption of web 2.0 technologies by experimental group at $\alpha=0.05$ in both experiments. Therefore, null hypothesis was again rejected.

\section{Discussion}

In this 21st century science and technology has materialized as one of the important subjects in our life as the theme of "web based educational technologies". Therefore a study was completed in which the researcher deliberates the effectiveness of web 2.0 tools in distance learning systems. This study was experimental in nature and the data obtained through the experiment which was analyzed, interpreted and conclusions were drawn. Statistical analysis of mean pretest posttest showed that significance of difference occurred, therefore, the null hypothesis was rejected.

Sutton, L. (2000, p. 102) concluded that through the limited literature review on the instructional scheme that the students in instructional strategy via pretest posttest approach were superior at knowledge application, problem definition and problem clarification. Therefore, it is stimulated that web 2.0 technologies enhances distance learner's lifelong learning skill by going beyond how to learn.

The results of this study publicized that pretest posttest approach via web 2.0 technologies enriches the academic achievement, problem solving skills and preservation of subject matter in distance learners. Therefore, it is advocated that web 2.0 technologies enhances and improve distance learner's lifelong learning skill by going beyond teaching gratified to teaching students how to learn. The inclusive results of the study showed that this strategy increased average retentive of distance learners than the learners taught without web 2.0 technologies. Hence the results of the study were, therefore, applicable in urban and rural distance learners of Pakistan, especially distance learners of Allama Iqbal Open University which disseminated throughout the country.

\section{Conclusions}


By a statistical analysis and findings of the study succeeding conclusions were drawn.

1. Web 2.0 tools were more effective than ordinary technologies in the increasing average academic achievement of distance learners.

2. Web skills more helpful in refining average problem solving proficiencies of distance learners as concomitant with traditional strategies.

3. 2.0 technologies were more useful in permitting increased average retentive of subject matter as compared to outmoded strategy.

4. This research study affirmed the possessions of web 2.0 tools on long-term examination.

\section{Recommendations}

In the light of the study following recommendations were made:

1. Tutors and distance learners may be capable for the use of information and communication technologies (ICTs).

2. There is a need to alter the workshops for distance learners through web 2.0 technologies so a committee of experts may be appointed to prepare a strategy.

3. Studies may be encouraged with DL's from different traditional backgrounds such as urban and rural areas with a larger sample.

4. Further studies may be conducted to investigate the effectiveness of web 2.0 technologies on different subjects at different levels of education.

\section{Suggestions for Future Research}

The study has recommended some lines for future research. Possibly the most important finding is that effectiveness is neither a single variable nor even a simple collecting of a small number of variables. There is a need to explore the nature of effectiveness much further. The key question is how to develop such characteristics. Are they simply characteristic? Do they develop with experience as this study recommends? Can they be enriched by means of any form of training? This needs foremost investigation, of course, the entire study allied to one definite test. There is an essential to enlarge this to other forms of assessment and other discussions of web 2.0 and higher such as web 3.0, $4.0 \& 5.0$ technologies.

\section{REFERENCES}

Al-Quran, Sura Al-Rehman.

Burners-Lee (1989). The Complete Guide for Teaching in Education via emerging technologies. London: International Publishing Group.

Das, B.C. (2000) Educational Technology. New Delhi: Kayani Publishers.

Dougherty, D. \&Dhanarajan (2004). Media live International. International Publishing Group. pp. 62-219.

Emdon, J.V. (2011) Effective Communication for Science and Technology. New York: P ALGRA VE. 
Harris, Smith \& Carry (2001). The Practice of web technologies in Teaching. Harlow: Pearson Education Ltd.

O'Reilly, T. (2005, September 30). What is Web 2.0: Design patterns and educational models for the next generation of software. Retrieved from the O'Reilly http://www.oreillynet.com/pub/a/oreilly/tim/news.

Redecker et al.,(2009). Emerging Web based Technologies. New Delhi: APH Publishing Corporation.

Sutton, L. (2000) vicarious interaction via web technologies: A learning theory for computer-mediatedcommunications. Glasgow: HarperCollins Publishers.

Seitzinger, J. (2006). Be constructive: Blogs and wikis as constructivist learning tools. New Delhi: APH Publishing Corporation.

Simons \& Salomon (2005). Social Aspects of Web Learning in Education. Review of Research in Education, 23, 1-24.

The Webster's Advanced Learner's English Dictionary. Glasgow: Harper Collins Publishing Corporation.

\section{WEB ADDRESSES}

http://books.google.com.pk/books

http://www .thefreedictionary.com/workshop.

http://www.itdl.org/journal

http://www.rdillman.com

http://www.aiou.edu.pk

http://www.emerging technologies.com

http://www.web technologies.com

http://www.oreillynet.com/pub/a/oreilly/tim/news

http://www.best tools for online learning.com 